\title{
サクションバケット基礎の一方向および繰返し 水平荷重に対する耐力特性評価
}

\author{
木村雄一郎 1 - Thaw $\operatorname{Tar}^{2}$ ・ 小野 泰明 2 -上田 恭平 3 - 渦岡 良介 4 \\ 1 正会員 日立造船（株）事業企画・技術開発本部 基盤技術研究所 \\ ( ( 551-0022 大阪市大正区船町 2-2-11) \\ E-mail:kimura@hitachizosen.co.jp \\ 2 日立造船（株）事業企画・技術開発本部 基盤技術研究所 \\ ( ( 551-0022 大阪市大正区船町 2-2-11) \\ 3 正会員 京都大学防災研究所助教（干611-0011 宇治市五ヶ庄） \\ 4 正会員 京都大学防災研究所教授（产611-0011 宇治市五ヶ庄）
}

\begin{abstract}
本研究では, 洋上風力風車基礎へのサクションバケット方式の適用にあたり，同方式の外力に対する支 持力特性を評価することを目的として，一方向水平荷重および繰返し水平荷重を複合的に組み合わせた荷 重条件を対象とした $1 \mathrm{G}$ 場における土槽実験を実施した。実験の結果，当該技術で先行する欧州における 既往の研究と整合する知見が得られ，当該基礎が有する終局的な耐力を基準とすることで，許容傾斜角を 満足する設計荷重の設定が可能であることを確認した。
\end{abstract}

Key Words : suction bucket, allowable inclination, repeated load, soil vessel experiment

\section{1. はじめに}

日本の洋上風力発電は, 先行する欧州と比較して気 象・海象，地艋条件，船舶等のインフラ整備の条件が異 なり, 発電コストが高いとされる. 今後, 固定価格買取 制度から自律した形での普及を目指寸中，洋上風力発電 の低コスト化は急務である. 洋上風力発電設備の基礎と して, 低コスト化への寄与が期待される構造物にサク ションバケット基礎がある. 同基礎は蓋を有し底が開口 した円筒状の構造物で，内部を減圧して圧力差により海 底地盤に貫入することを最大の特徵とし, 貫入後, 海洋 施設の基礎として利用できる. 本構造物は, 堆積層の薄 い海底地盤に適用でき，大型の施工機械が不要であるこ とから，モノパイル基礎と比較してコスト低減が可能な 工法として欧州では商用機の導入が始まっている．洋上 風力発電における主要な基礎形式を図-1に示寸.

そこで，本研究では，日本近海における着床式洋上風 力発電設備の基礎としてのサクションバケット基礎の適 用性を確かめることを目的とし，一方向荷重と繰返し荷

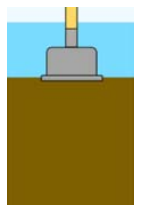

(a) 重力式

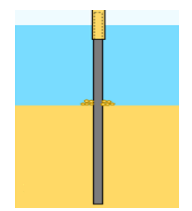

(b) モノパイル式

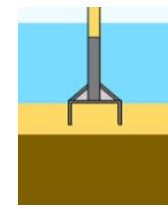

(c) サクション式
図-1 基礎形式の比較（茶色は岩盤層を示寸）
重とを組み合わせた外力に対する耐力特性を実験的に評 価した. 併せて, 本研究を通して得た知見と欧州の先行 文献との整合性についても確認した.

\section{2. 一方向水平載荷実験}

\section{(1) 試験装置}

実験土槽は，内寸が $988 \mathrm{~mm} \times 948 \mathrm{~mm} \times 644 \mathrm{~mm}(\mathrm{H})$ と なる十分な岡性を有する鋼製容器に, 豊浦砂を水中落下 法にて投入することで構築した. 比較的密な地盤を作成 するため, 突き棒により随時締固めを行いながら砂を投 入した結果, 相対密度が $77.1 \%$ となる実験土槽を得た. 豊浦砂の代表的な物性を表-1 に示す。

試験体への載荷には，一軸アクチュエータを用いた. アクチュエータと試験体とは，ローラとピンを介して荷 重伝達させることで，水平力以外が伝達されない構成と した. バケットへの載荷に伴ってアクチュエータに生じ る反力は，鋼製容器に固定された支柱で支持する構造と した. 試験装置の構成を図-2 に示寸.

アクチュエータによる水平力によって生じる試験体 の傾きは，図-3 のように，変位計を 2 台配置することで 測定した. 試験体傾斜角の他，アクチュエータの押付け 力およびストロークを計測した. 計測のサンプリング周 波数は, 実験条件に応じて $20 \sim 1,000 \mathrm{~Hz}$ の範囲とした. 試験体となるバケットは，ポンプを利用した減圧装置 
を用いて，実機と類似する方法で負圧により実験土槽に 貫入し，バケット天端面が地盤に着底していることを確 認した．実験結果のばらつきが小さかったことから，サ

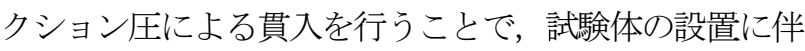
う実験地盤の変化は最小限に抑制できたと推定される.

\section{(2) 試験体}

本実験に用いた試験体の寸法を表-2 に示寸. バケット の直径 $D$ が $12 \mathrm{~m}$, 高さ $L$ が $10 \mathrm{~m}$ となる設備を想定実機 とし, 縮尺比 $\lambda$ が $1 / 28.5,1 / 33.3$ あるいは $1 / 40$ となる 3 種類の直径を有する試験体を用いた. 高さについても同 じ縮尺比で模型化したものを基本とするが，1/33.3 ス ケールの模型については，高さを $50 \mathrm{~mm}$ あるいは 100 $\mathrm{mm}$ 短く製作した模型も実験の対象とした.

直径 $12 \mathrm{~m}$, 高さ $10 \mathrm{~m}$ を有する基準寸法となるバケッ トの縦横比 $L / D$ は 0.83 である. 他方, $1 / 33.3$ スケールに おいて縦方向寸法を $50 \mathrm{~mm}$ 縮小した模型の縦横比 $L / D$ は 0.69 , 同縦方向寸法を $100 \mathrm{~mm}$ 縮小した模型の縦横比 $L / D$ は 0.56 となる.

実機は鋼構造であり，直径 $12 \mathrm{~m}$ を有する実機の側壁 部の板厚は $30 \mathrm{~mm}$ 程度を想定する. 模型の同部について

表-1 豊浦砂の代表的な物性

\begin{tabular}{|c|c|c|c|}
\hline 比 重 & 最大粒径 & 最大乾燥密度 & 最小乾燥密度 \\
\hline \hline $2.655\left[\mathrm{~g} / \mathrm{cm}^{3}\right]$ & $0.850[\mathrm{~mm}]$ & $1.664\left[\mathrm{~g} / \mathrm{cm}^{3}\right]$ & $1.364\left[\mathrm{~g} / \mathrm{cm}^{3}\right]$ \\
\hline
\end{tabular}

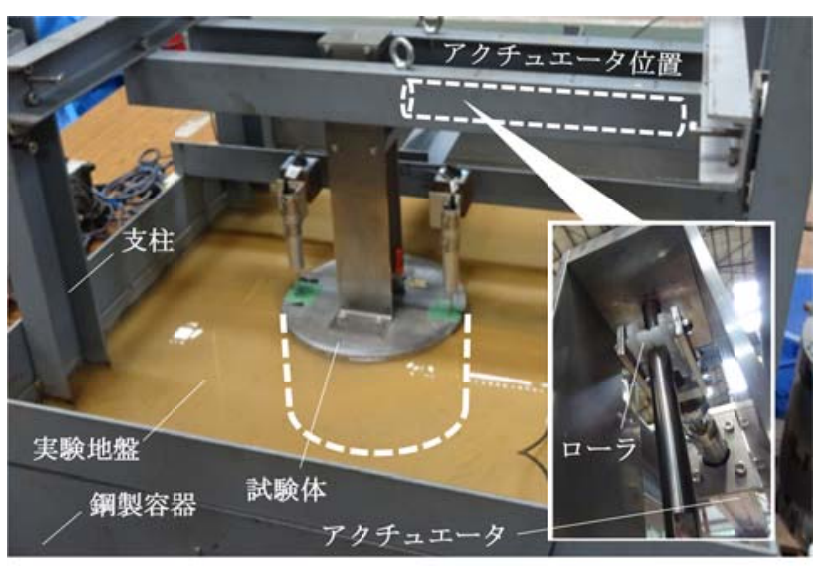

図-2＼cjkstart実験装置の概略

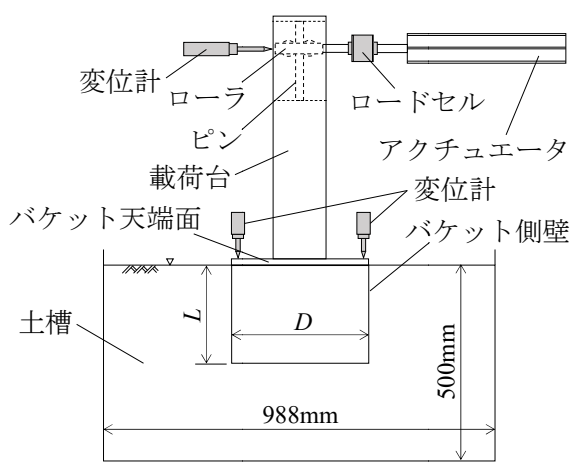

図-3 試験体側面図と計測機器の配置
も縮尺比に従い寸法を設定する必要があるものの，Iai (1989)の方法 ${ }^{1)}$ に沿って算定される寸法は $0.5 \mathrm{~mm} \sim 0.8$ mm にあたる. 模型はステンレス鋼 (SUS304)にて製作し たが，板厚 $1 \mathrm{~mm}$ 以下の薄板では製作性が確保できない ため, いずれの縮尺模型の側壁部も $1 \mathrm{~mm}$ の厚さとした.

想定実機における上部構造物（主塔および風車）の重 量を $350 \mathrm{t}$ と設定すると, 単位面積あたりの鉛直地盤反力 は $30.35 \mathrm{kPa}$ となる。 これを，縮尺比 1/28.5，1/33.3 ある いは $1 / 40$ の模型に付与寸る場合， $1 \mathrm{G}$ 場における相似則 を考慮すると, 各試験体一の上載重量は $15.0 \mathrm{~kg}, 9.45 \mathrm{~kg}$ あるいは $5.47 \mathrm{~kg}$ とそれぞれ換算される.本実験て使用寸 る試験体は，これらを目標として差が $\pm 5 \%$ 以内となるよ う設計した。

\section{(3) 試験条件}

一方向水平載荷実験の試験条件を表-3 亿示寸. 本実験 では，模型の縮尺に加え，水平荷重を加える速度を実験 のパラメータとした．載荷量は，バケット天端から 400 $\mathrm{mm}$ の高さの位置を $20 \mathrm{~mm}$ 水平に変位させる量 (約 0.05 rad）を目安とした. この傾斜觕は，欧州の基準において 風力発電用風車基礎に要求される許容傾斜量（1/200 以 下）の 10 倍に相当するが, 当該基礎の転倒時における回 転中心が不明であるため, $0.05 \mathrm{rad}$ の傾斜角を厳密に再現 するものではない.

載荷速度は, 排水条件を想定して $1,000 \mathrm{~s}$ 間で上記載荷 量を加える場合, 非排水条件を想定して $1 \mathrm{~s}$ 間で上記載 荷量を加える場合の 2 ケースに加え，これらの中間的な 条件として，同載荷量を $100 \mathrm{~s}$ 間あるいは $10 \mathrm{~s}$ 間で加え るケースを条件とした．ここでは，模型スケールを変え た実験ケースであっても，載荷速度の調整は行わない． アクチュエータによる押付け力を開放した際のバケット の挙動を確認するため, $20 \mathrm{~s}$ 間の姿勢保持後, 載荷速度 $5 \times 10^{-3} \mathrm{ad} / \mathrm{s}$ に相当寸る速度で除荷を行い，その過程につ いても計測の対象とした.

実験の再現性を得るため, 同一の条件で少なくとも 5 回の計測を行った.

表-2 試験体の寸法（長さの単位：mm）

\begin{tabular}{|l|c|c|c|c|c|}
\hline 略 称 & D420 & D360a & D360b & D360c & D300 \\
\hline \hline 縮尺比 & $1 / 28.5$ & \multicolumn{4}{|c|}{$1 / 33.3$} \\
\hline 直 径 & 420 & \multicolumn{3}{|c|}{360} & $1 / 40$ \\
\hline 高 さ & 350 & 300 & 250 & 200 & 250 \\
\hline 縦横比 & 0.83 & 0.83 & 0.69 & 0.56 & 0.83 \\
\hline
\end{tabular}

表-3 一方向載荷実験における実験パラメータ

\begin{tabular}{|c|c|}
\hline & \multicolumn{2}{|c|}{ 試験条件 } \\
\hline \hline 載荷量 $[\mathrm{rad}]$ & $0.05($ 目安 $)$ \\
\hline 載荷速度 $[\mathrm{rad} / \mathrm{s}]$ & $5 \times 10^{-5}, 5 \times 10^{-4}, 5 \times 10^{-3}, \quad 5 \times 10^{-2}$ \\
\hline
\end{tabular}




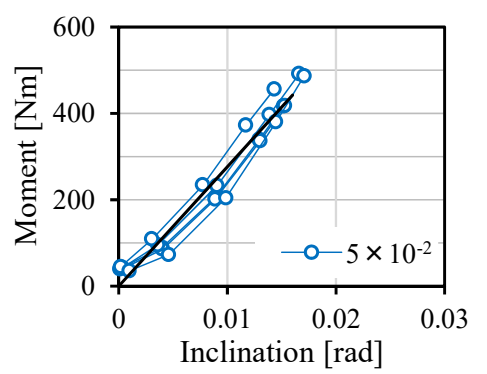

(a) 非排水条件

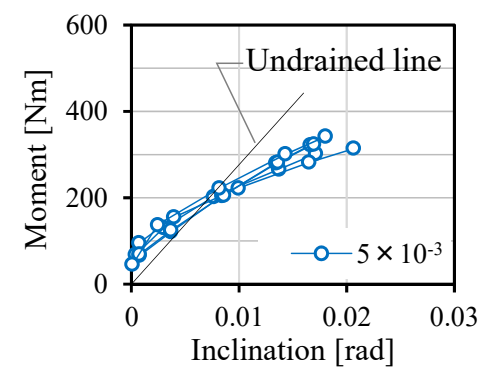

(b) 部分排水条件

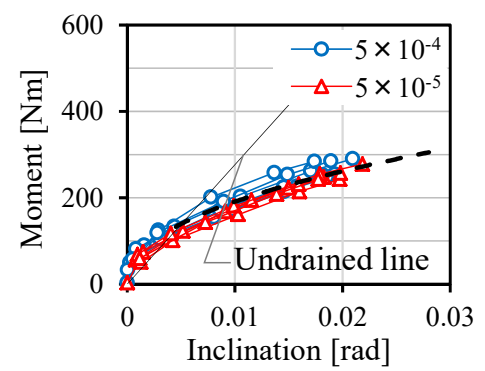

(c) 排水条件

図-4 水平載荷に伴う傾斜角（D420 型模型を対象とした試験ケース，凡例は載荷速度 $[\mathrm{rad} / \mathrm{s}]$ ）

\section{（4）実験結果}

\section{a) 傾斜角}

表-2 に示す D420 型試験体について，水平載荷に伴っ て生じた試験体の傾斜角と，バケットの天端面を回転の 基準とした載荷モーメントとの関係を図-4 に示す. $5 \times$ $10^{-2} \mathrm{rad} / \mathrm{s}$ の角速度で載荷したケースは，地盤が有する透 水係数と比較して十分に速い速度で載荷しており，かつ 傾斜角と載荷モーメントとの関係が線形的であることか ら, 非排水条件とみなした. 他方, $5 \times 10^{-4}$ および $5 \times 10^{-5}$ $\mathrm{rad} / \mathrm{s}$ の角速度で載荷重したケースは, 双方の結果に顕著 な差異がみられなかったことから, 十分に遅い速度で載 荷されたものと判断し, 排水条件として分類した. また,

これらの分類に伴い，非排水条件と排水条件との中間に 位置する $5 \times 10^{-3} \mathrm{rad} / \mathrm{s}$ の角速度で載荷したケースを部分 排水条件とした.

図-4 より，排水条件下で実施した試験ケースは，変位 角の増加に伴い，傾斜角と載荷モーメントとの線形関係 は失われ，対数関数的な傾向を示した. 本実験結果の範 井では，双方の関係は，指数が 1 未満の正の数となる単 項の累乗関数で近似できる傾向がみられた。こうした傾 向は，他の模型を対象としたケースでも同様であり，次 項において終局荷重を評価する際，双方の関係の外挿に 同関数を用いた.

\section{b) 終局荷重}

排水条件下において地盤が支持しうる終局的な荷重 $F_{u l t}$ を評価するため, 前記累乗関数による近似曲線を用い て横軸正方向に曲線を延長したものを図-5に示す.

一般的に，実験における終局荷重は，地盤が降伏する まで水平載荷した上で, 地盤反力がある值に収束した際 の荷重を終局值と定義する，ただし，本実験では，実験 地盤を繰返し使用したため，実験ケース毎に地盤が降伏 するまでの載荷を行った場合，地盤性状に変化を与える 可能性がある. このため, Nielsen ら(2017)による研究 ${ }^{2)}$ を参考に，傾斜角と水平荷重との関係を示す曲線に対し て，載荷初期の接線と載荷後期の接線（傾斜角 $0.1 \mathrm{rad}$ 時 における接線）との交点を終局荷重として定義した.

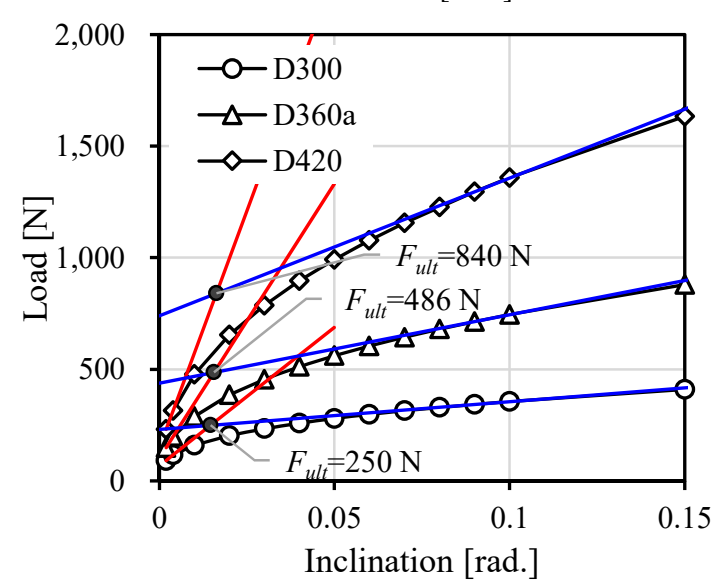

(a) 縦横比 0.83 のケース

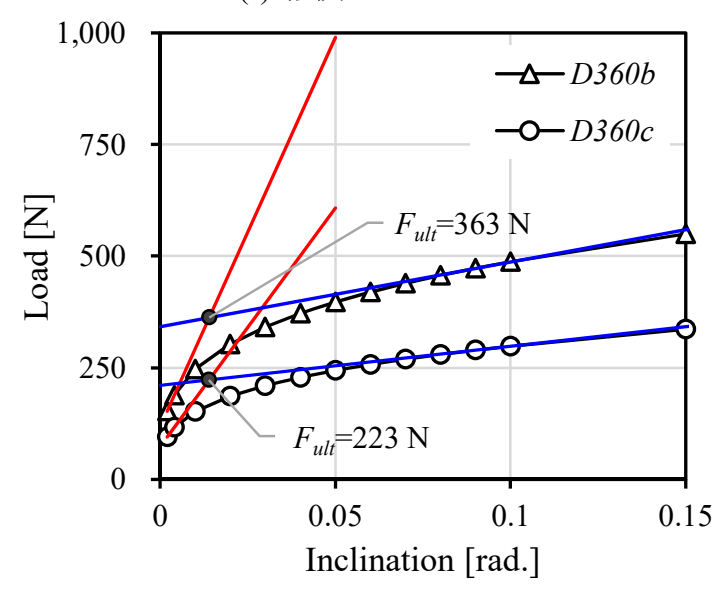

(a) 縦横比 0.56 および 0.69 のケース

図-5 終局荷重の定義

表-4 終局荷重および終局モーメント

\begin{tabular}{|c|c|c|c|}
\hline \multirow{2}{*}{ 縦横比 } & 試験体 & $\begin{array}{c}\text { 終局荷重 } \\
F_{\text {ult }}[\mathrm{N}]\end{array}$ & $\begin{array}{c}\text { 終局モーメント } \\
M_{\text {ult }}[\mathrm{Nm}]\end{array}$ \\
\hline \hline \multirow{3}{*}{0.83} & $\mathrm{D} 300$ & 249.6 & 99.8 \\
\cline { 2 - 4 } & $\mathrm{D} 360 \mathrm{a}$ & 485.9 & 194.4 \\
\cline { 2 - 4 } & $\mathrm{D} 420$ & 839.9 & 336 \\
\hline 0.56 & $\mathrm{D} 360 \mathrm{~b}$ & 223 & 89.2 \\
\hline 0.69 & $\mathrm{D} 360 \mathrm{c}$ & 362.7 & 145.1 \\
\hline
\end{tabular}

本実験における終局荷重および終局モーメントを表-4 に示す.ここで示した終局荷重および終局モーメントは, 次章にて述べる繰返し載荷実験結果の無次元化にて使用 する. 


\section{3. 繰返し水平載荷実験}

\section{(1) 試験装置}

一方向載荷実験と同一の実験装置を使用したが，土槽 は再構築した. 前述と同様の方法で豊浦砂を投入し, 結 果，相対密度 $79.2 \%$ の実験地盤を得た. 双方の実験地盤 における相対密度の差は $2 \%$ 程度と小さく, 結果を比較 する上で有意な差異はないものと判断した.

計測機器および試験体は，一方向載荷実験と同一のも のを使用した. 計測のサンプリング周波数は $100 \mathrm{~Hz}$ とし た.

\section{(2) 試験条件}

繰返し水平載荷実験では，一方向水平載荷実験にて取 得した終局荷重 $F_{u l t}$ を基準に，一方向荷重 $F_{a}$ と繰返し荷 重振幅 $F_{c y c}$ を組久合わせた複数の条件を載荷の目標值と した，一方向荷重と繰返し荷重の定義を図-6，載荷重の 目標值を表-5 に示寸．荷重の作用位置は，一方向水平載 荷実験と同様, バケット天端から $400 \mathrm{~mm}$ の高さとした.

繰返し荷重による地盤耐力の低下，つまり，間隙水圧 の上昇は，非排水条件のもとで生じる，従って，載荷周 期は，完全非排水条件に近づけるよう，できるだけ短周 期であることが望ましいが，使用したアクチュエータの 性能から載荷周期は約 $2 \mathrm{~s}$ となった。 この載荷速度は, 一方向水平載荷実験における非排水条件時の速度と比較 してやや遅く完全非排水条件とはいえないものの，間隙 水圧が十分に消散しない条件の範囲と考えられる.

載荷回数は約 500 回とした. 実験の再現性を確認する ため, 表- 5 記載の各試験ケースとも同一条件で 3 回ずつ の計測を行った。

\section{(3) 試験結果}

\section{a) 地盤耐力の変化}

水平面を基準とした振動中心 $\theta_{c-m}$ と傾斜振幅 $\theta_{a-m}$ あた りのモーメントとの時間変化の一例を図-7 にそれぞれ 示す。ここで， $\theta_{c}$ および $\theta_{a}$ の定義を図-8に示寸．添え字

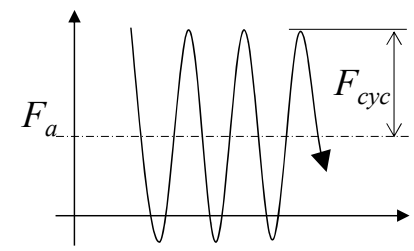

図-6 一方向荷重と繰返し荷重の定義

表-5 繰返し載荷実験における荷重条件

\begin{tabular}{|c|c|c|c|c|c|c|c|}
\hline & No.1 & No.2 & No.3 & No.4 & No.5 & No.6 & No.7 \\
\hline \hline$F_{a} / F_{\text {ult }}$ & 0 & 0.1 & 0.3 & 0 & 0 & 0.1 & 0 \\
\hline$F_{\text {cyc }} / F_{\text {ult }}$ & 0.9 & 0.8 & 0.6 & 0.7 & 0.6 & 0.2 & 0.2 \\
\hline
\end{tabular}

の $m$ は模型スケールであることを示す．また，凡例に示 す $A L R$ および $C L R$ とは, 一方向荷重 $F_{a}$ および繰返し荷 重振幅 $F_{c y c}$ を終局荷重 $F_{u l t}$ でそれぞれ除した值を示し,以 下，それぞれを一方向荷重強度および繰返し荷重振幅強 度と呼称する。

図-7(a)より，一方向荷重を与えなければ，繰返し荷重 振幅強度の大小に関わらず，水平面を基準とした振動中 心 $\theta_{c-m}$ の傾倒は軽微であることがわかる。.また，図-7(b)

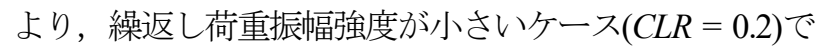
は，単位傾斜振幅 $\theta_{a-m}$ あたりのモーメントの変化は小さ いものの, 繰返し荷重振幅強度が大きいケース $C L R$ ミ0.8)では，同モーメントは徐々に低下しており，地盤 の支持力が低下していることがわかる．この地盤支持力 低下の要因が地盤内間隙水圧の上昇によるものと考えら れるが，地盤内の水理現象が完全な非排水条件ではない ため, 地盤耐力低下の傾向は比較的緩やかであるといえ る.

\section{b) 許容傾斜角}

横軸を一方向荷重強度 $A L R$, 縦軸を繰返し荷重振幅強 度 $C L R$ とした, 約 500 回の載荷後における水平面に対す

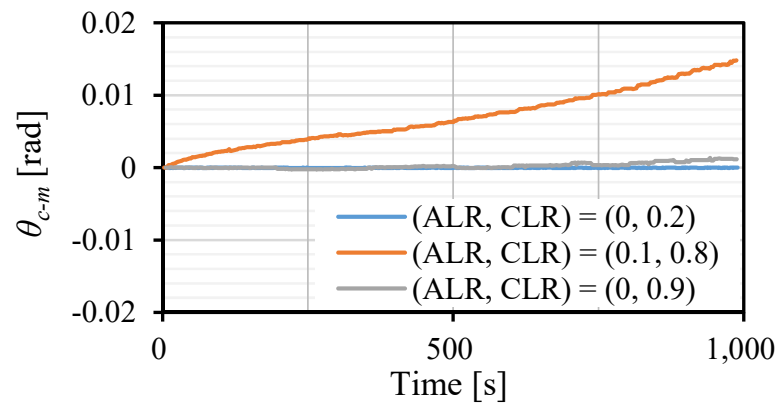

（a）水平面を基準とした傾斜角

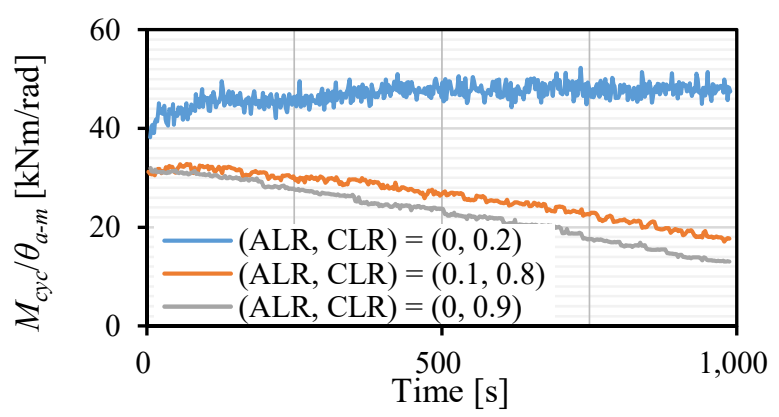

(b) 単位傾斜振幅あたりのモーメント

図-7 繰返し載荷による傾斜角の時間変化の一例 (D300)

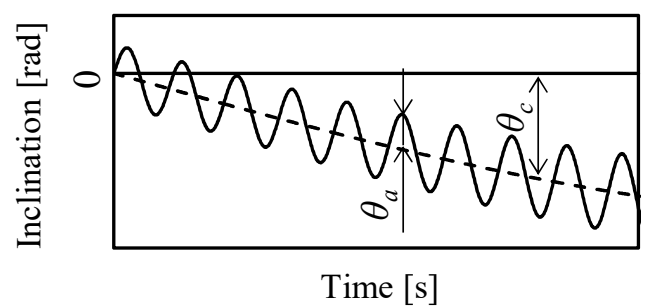

図-8 傾斜角の定義 
る実機スケールにおける傾斜角 $\theta_{c-p}$ を図-9 に示寸（添え 字の $p$ は実機スケールであること示す).試験体の寸法変 化に伴う傾斜角の傾向に差異がみられなかったことから， 図-9 では，5 型式の試験体を対象としたすべての実験結 果を合わせて示した. さらに, 1,000 回の繰返し載荷を通 して許容載荷条件を算出した Nielsen ら(2017)の実験結果 2)についても同図に併記した.

図-9 より, 繰返し荷重振幅強度が 0.2 を下回るケース では，繰返し載荷後における傾斜角がおよそ $1 / 400$ 以下 となった．また，前項にて記したように，一方向荷重強 度が 0 近傍となるケースでは, 繰返し荷重振幅強度が比 較的大きい場合であっても傾斜角の進展は小さい.

2(3)節に記したように，欧州における風車基礎構造物 の許容傾斜角は $1 / 200$ である. 本実験における載荷回数 は, Nielsen らの実験と比較して約 500 回と少ないが, 傾 斜角 $\theta_{c-p}$ が 1/400 以下となるケースでは, 繰返し載荷をさ らに継続させても傾斜角の進展がほぼみられなかった. 従って，本実験では，十分な安全率を確保した検討とす るため, 傾斜角 $\theta_{c-p}$ が $1 / 400$ 以下となる荷重条件を許容 值として設定する.

図-9 中に傾斜角 $1 / 400$ を満たす許容荷重の閾值を破線 で表示した。 この破線は, Nielsen らによる非排水条件で の閾値とほぼ一致することがわかる.

\section{c）地盤強度変化の傾向と載荷条件との関係}

次に, 単位傾斜振幅あたりのモーメント $M_{c y d} d \theta_{a-m}$ と繰 返し載荷回数との関係から，図-7(b)にて示した地盤耐力 の低下傾向を比較寸る. ここでは, 図-10に示すように, 繰返し載荷に伴って単位傾斜振幅あたりのモーメントが 減少するケース (二点破線) を過剩間隙水圧による耐力 低下，繰返し載荷に伴って同モーメントが増加するケー ス（破線）を砂の密実化による耐力上昇とし，各曲線の 傾き $\beta$ を地般強度変化率と呼称する.

横軸を一方向荷重強度 $A L R$, 縦軸を繰返し荷重振幅強 度 $C L R$ として, 繰返し載荷に伴う地盤強度变化率 $\beta$ の分 布を図-11 に示す。ここでは，データのばらつきを考慮

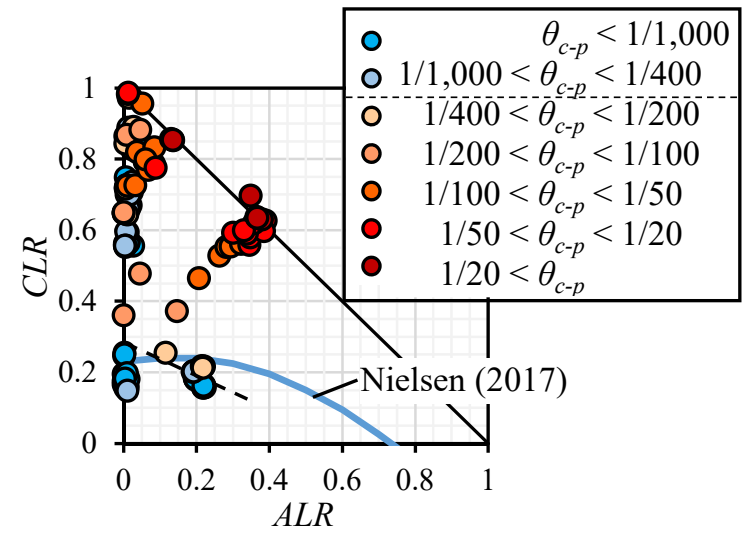

図-9 繰返し載荷後における水平面を基準とした傾斜角
して, 地盤強度変化率 $\beta$ が 0 から 0.15 の範囲に留まった ケースを遷移的な状態であるとし， $\beta<0$ を「過剩間隙水 圧」, $\beta>0.15$ を「密実化」として分類した. この図より, 繰返し荷重振幅強度 $C L R$ が大きく一方向荷重強度 $A L R$ が小さいケースでは耐力低下が顕著となり，一方向荷重 強度 $A L R$ が比較的大きければ砂地盤の密実化によって 地盤の耐力低下が抑制されることが確認できた。

Nielsen らは, 繰返し載荷による地盤耐力への影響の大 小を図-12 のように結論づけている ${ }^{2}$. 本実験結果による 「過剩間隙水圧」あるいは「密実化」が示寸領域とは, 地盤内の水理条件が異なるため定量的には一致しないも のの，定性的には地盤の特性を捕捉できていることがわ かる。

\section{d) 鉛直変位}

試験体に繰返し荷重を作用させると，試験体が徐々に 鉛直上向きに変位する傾向がみられた，本実験における 試験体の鉛直変位速度を荷重条件毎の分布として図-13

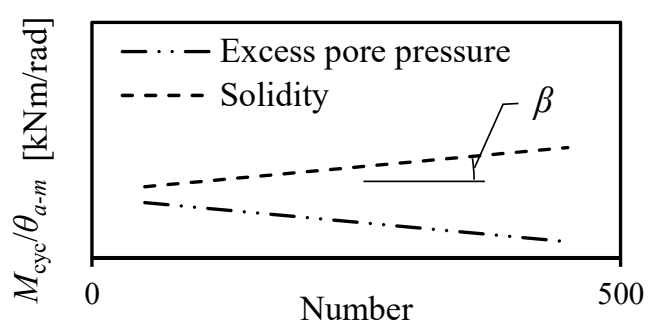

図-10＼cjkstart地盤強度変化率の定義（単位 : rad）

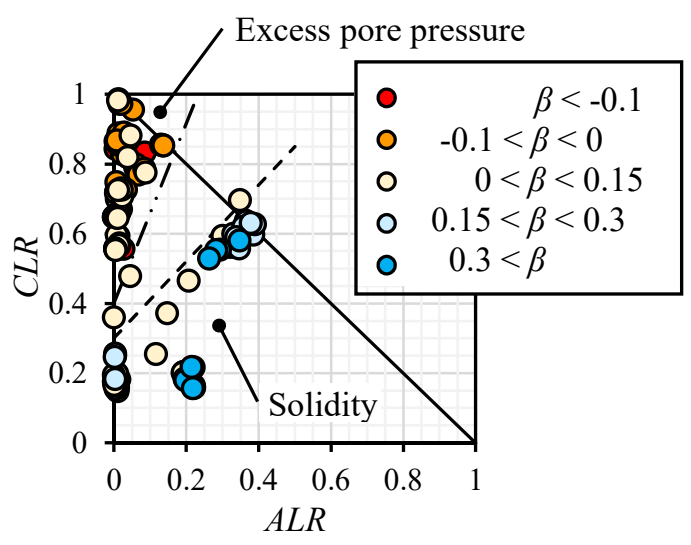

図-11 載荷条件の変化に伴う地盤強度変化率の差異

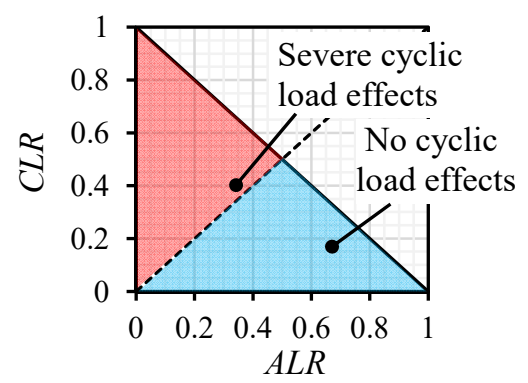

図-12 Nielsen らによる繰返し載荷の影響範囲 
に示す. 図-9 および図-11 と同様, 図-13 の横軸は一方向 荷重強度 $A L R$, 縦軸は繰返し荷重振幅強度 CLR をそれ

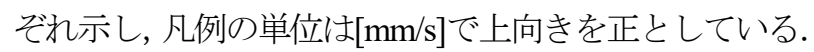

図中の青色の丸印は, 上向き速度が $10^{-3} \mathrm{~mm} / \mathrm{s}$ 以下とな る条件を示す. 1 ケースの繰返し載荷試験における計測 時間が約 $1,000 \mathrm{~s}$ であることから，この変位量は $1 \mathrm{~mm}$ 以 下に相当する．このようなケースについては，鉛直変位 がほぼ生じていないとみなすことができる. 図中の破線 は，傾斜角が許容範囲となるための荷重条件を示すが， この破線以下の載荷条件であれば鉛直変位もみられない. つまり，傾斜角に関する荷重条件を満たすことで，鉛直 変位についても適切に抑制できていることが確認された。

繰返し載荷によって鉛直変位が発生する要因は，バ ケットの押込み抵抗と引抜き抵抗に差があることが主な 理由と考えられる. 押込み抵抗は周面抵抗と先端抵抗の 合計となるが，引抜き抵抗は周面抵抗のみとなる. 水平 荷重を伴う外力によってサクションバケット基礎にモー メントが生じる際，図-14 に示すように，水平外力の風 下側のバケット側壁には押込み力, 同外力の風上側には 引抜き力が発生する. 静止摩擦力の範囲で支持可能な外 力であればバケットに変位は生じないが，バケットが変 位を伴う水準の負荷に対しては，押込み力に対する変位 量と比較して引抜き力による変位量が大きくなる.こう した現象を繰返すことで，バケットは徐々に上向きに変 位すると考えられる.

\section{4. おわりに}

本研究では，サクションバケット基礎の着床式洋上風 力発電設備基礎としての適用性を確かめることを目的と し，1G 場において，一方向荷重と繰返し荷重を対象とし た小型の土槽実験を実施した. 本研究の結果, 基礎の傾 斜角が許容範囲となるための外力条件を整理でき，こう した許容荷重の範囲での載荷であれば, 傾斜だけでなく, 変位も抑制できることが確認された。

また， $1 \mathrm{G}$ 場の小型実験では有効土圧が小さく，スケー ル影響が排除しきれないことから, 直径 $12 \mathrm{~m} の$ 実機を基

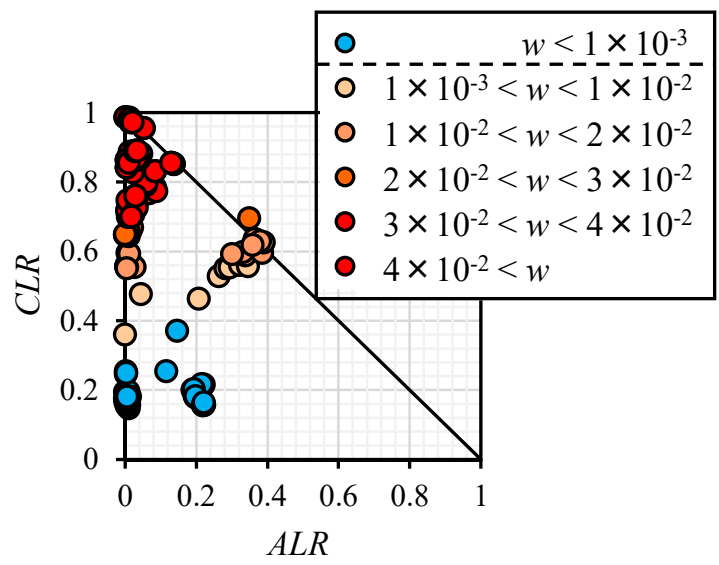

図-13 繰返し載荷に伴う鉛直変位（単位 : $\mathrm{mm} / \mathrm{s}$ )

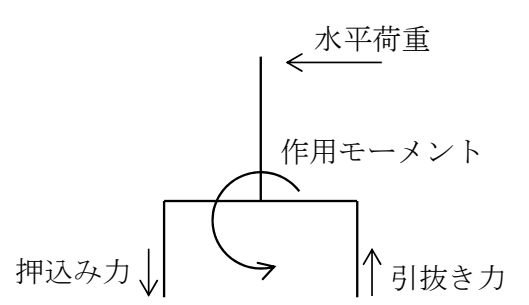

図-14 水平荷重に伴う押込み力と引抜き力

準として 1/8 スケール程度の模型を対象とする大型の 土槽実験も計画中である.

本基礎形式を風車基礎構造物として適用するために は，主塔や風車の固有振動の影響を評価することが必須 となる。こうした影響評価は，模型実験では容易ではな いことから, 数值シミュレーションも併用して信頼性確 保のための取り組みを継続する.

\section{参考文献}

1) Iai, S. (1989): "Similitude for Shaking Table Tests on Soil-Structure-Fluid Model in 1g Gravitational Filed", SOILS AND FOUNDATION, Japanese Geotechnical Society, Vol. 39, No.5, pp.61-71.

2) Soren Dam Nielsen et al. (2017): "Response of Cyclic-Loaded Bucket Foundations in Saturated Dense Sand", J. Geotech. Geoenviron. Eng., Vol. 143(11), 04017086.

(Received February 6, 2020)

(Accepted May 1, 2020)

\section{EXPERIMENTAL STUDY FOR SUCTION BUCKET FOUNDATION IN RESPONSE TO UNIDIRECTIONAL LOAD AND REPEATED LOAD}

\section{Yuichiro KIMURA, Thaw TAR, Yasuaki ONO, Kyohei UEDA and Ryosuke UZUOKA}

In this study, in applying the suction bucket structure to the foundation of an offshore wind turbine, in order to evaluate the bearing force characteristics of the structure against unidirectional horizontal loads and repeated horizontal loads, a soil vessel experiment was carried out in $1 \mathrm{G}$ gravitational field. Through this study, the experimental result was consistent with previous studies in Europe that were prior to this technology. Moreover, it was possible to set the design load that satisfies the allowable inclination angle by using the ultimate strength of the structure. 